\title{
Kontribusi Kemenarikan Interpersonal Konselor pada Motivasi Siswa dalam Mengikuti Bimbingan Kelompok di Kota Malang
}

\author{
Guruh Sukma Hanggara, Nora Yuniar Setya Putri
}

KORESPONDEN PENULIS:

Guruh Sukma Hanggara

Universitas Nusantara PGRI Kediri Jalan. K.H. Achmad Dahlan Nomor.

76, Kota Kediri, Jawa Timur, Indonesia Email: kangguruh@gmail.com

Nora Yuniar Setya Putri

Universitas Nusantara PGRI Kediri Jalan. K.H. Achmad Dahlan Nomor. 76, Kota Kediri, Jawa Timur, Indonesia Email:kangguruh@gmail.com

Halaman

$36-44$

\begin{abstract}
This study aimed to find out the relationship between the counselor' interpersonal attractiveness and the students' motivation in participating the group guidance. This was a correlational study. The subject of this study was 246 students of the eleventh grade of state senior high schools in Malang city as the respondents. The subject of this study was taken by cluster random sampling technique. This study employed Pearson product-moment correlational test to analyze the data. The result of this study showed a positive and significant relationship between the counselor' interpersonal attractiveness and state senior high school students' motivation in participating group guidance by $(r=0.622)$ and $(p=0.000<0.05)$. Higher counselor' interpersonal attractiveness leads to higher students' motivation in participating group guidance. This study proved the importance of the counselor' interpersonal attractiveness in providing group guidance so that the students are highly motivated to participate in group guidance service.

Keywords: interpersonal attractiveness, motivation, group guidance
\end{abstract}

\section{ABSTRAK}

Studi ini bertujuan untuk mengetahui kontribusi kemenarikan interpersonal konselor pada motivasi siswa dalam mengikuti bimbingan kelompok. Jenis penelitian dalam studi ini adalahkorelasi dengan subyek siswa SMA negeri di kota Malang kelas sebelas dengan jumlah 246 responden yang diambil dengan teknik cluster random sampling. Teknik analisis data dalam studi ini menggunakan uji korelasi product moment pearson. Hasil studi menunjukkan terdapat hubungan yang positif dan signifikan antara kemenarikan interpersonal konselor dan motivasi siswa SMA Negeri dalam mengikuti bimbingan kelompok dengan $(r=0,622)$ dan $(p=0,000<0,05)$. Semakin tinggi kemenarikan interpersonal konselor maka semakin tinggi pula motivasi siswa dalam mengikuti bimbingan kelompok.Studi ini membuktikan pentingnya kemenarikan 
interpersonal konselor dalam memberikan layanan bimbingan kelompok supaya siswa memiliki motivasi yang tinggi dalam mengikuti layanan bimbingan kelompok.

Kata kunci:kemenarikan interpersonal, motivasi, bimbingan kelompok.

\section{PENDAHULUAN}

Fenomena di sekolah menunjukkan bahwa masih banyak siswa yang kurang memiliki motivasi dalam mengikuti layanan bimbingan, khususnya bimbingan kelompok. Kurangnya motivasi siswa dalam mengikuti kegiatan dalam layanan bimbingan dan konseling bisa ditunjukkan dengan perilaku seperti kurangnya partisipasi siswa dalam kegiatan yang diberikan, membuat gaduh suasana kelas saat ada kegiatan bimbingan, tidak memperhatikan ketika konselor sedang menjelaskan materi atau lebih parah mereka enggan mengikuti kegiatan dengan cara meninggalkan kelas beguitu saja atau dari awal mereka sudah tidak ada dalam kelas sejak jam bimbingan dimulai dan masih banyak yang lainnya. Siswa kurang memiliki motivasi dalam mengikuti bimbingan karena dirasa tidak menyenangkan, tidak menarik, atau karena memang tidak berpengaruh pada nilai raportnya sehingga tidak dirasa terlalu penting untuk diikuti.

Motivasi siswa merupakan hal pokok yang penting untuk dibangkitkan, sebagai penopang akan terciptanya keefektifan dalam penyelenggaraan bimbingan kelompok (Irawan, 2012). Salah satu cara yang dapat ditempuh adalah dengan meningkatkan kemenarikan interpersonal konselor. Jadi, kemenarikan interpersonal konselor merupakan salah satu pembangkit motivasi siswa dalam mengikuti bimbingan. Rahmat (2005:110-111) menyatakan bahwa kesukaan pada orang lain, sikap positif dan kemenarikan seseorang, disebut sebagai atraksi interpersonal. Kemenarikan interpersonal merupakan syarat untuk berkomunikasi dengan orang lain dengan lebih efektif. Salah satu metode yang digunakan untuk meningkatkan efektifitas komunikasi salah satunya bahwa, pengirim pesan harus memastikan bahwa calon penerima pesan memperhatikan dirinya (Hanurawan, 2007). Hal ini mendukung pernyataan sebelumnya, sehingga dengan semakin tingginya kemenarikan interpersonal yang dimiliki seseorang maka komunikasi yang dilakukan orang itu akan semakin efektif.
Konselor yang tidak mempedulikan akan pentingnya kemenarikan interpersonal dalam interaksinya khususnya dalam berinteraksi dengan siswa, maka ia kurang disukai oleh siswanya, dianggap kurang penting peranannya, dan cenderung akan diabaikan oleh siswa (Gumilang, 2015). Akibat lebih lajut dari diabaikanya konselor karena tidak memiliki kemenariakan interpersonaladalah bimbingan yang diberikan tidak akan efektif, tidak mencapai sasaran yang diinginkan, dan tujuan pendidikan yang sebenarnya tidak akan tercapai. Apabila fenomena itu tidak ditanggulangi maka kedudukan dan fungsi BK di sekolah tidak akan efektif.Makaperlu untuk mengkaji secara mendalam tentang hubungan kemenarikan interpersonal konselor dan motivasi siswa dalam mengikuti bimbingan kelompok di kota Malang. Studi ini bertujuan untuk mengetahui adanya hubungan antara kemenarikan interpersonal konselor dan motivasi siswa SMA Negeri dalam mengikuti bimbingan kelompok di kota Malang. Temuan studi ini menjadi salah satu alternatif bagi guru bimbingan dan konseling untuk meningkatkan motivasi siswa dalam mengikuti layanan bimbingan kelompok.

\section{METODE}

Studi ini merupakan penelitian korelasi. Subyek dalam studi ini adalah siswa SMA Negeri di Kota Malang kelas XI berjumlah 246 responden. Instrumen yang digunakan berupa angket. Teknik analisis data dalam studi ini menggunakan ujikorelasi product moment pearson. Analisisdeskriptif ditempuh untuk menjabarkan karakteristik dari masingmasing variabel. Sedangkan uji prasyarat dilakukan supaya syarat dan kelayakan untuk melakukan uji hipotesis terpenuhi.

Selanjutnya uji hipotesissendiri untuk mengetahui derajat kedekatan hubungan antara kemenarikan interpersonal konselor $(X)$ dan motivasi siswa dalam mengikuti bimbingan kelompok (Y). Teknik analisis deskriptif yang dimaksudkan meliputi presentase dan kualifikasi masing-masing variabel. Sedangkan uji prasyarat meliputi uji normalitas yang di tempuh dengan menggunakan uji kolmogorov-simirnov, dan uji linieritas Uji linieritas dilakukan membandingkan signifikansi hasil penghitungan dengan $(\alpha=0,05)$ bila (signifikansi hitung) $<$ dari $(=0,05)$ maka sebaranya dikatakan linier. Selain itu juga dapat dketahui dengan membandingkan $\left(\mathrm{F}_{\text {hitung }}\right)$ dengan $\left(\mathrm{F}_{\text {tabe }}\right)$, bila $\left(\mathrm{F}_{\text {nitung }}\right)>(\mathrm{F}$ tabel) maka sebaran variabelnya juga linier dan sebaliknya. 
Beda halnya dengan uji hipotesis yaitu untuk mengetahui besarnya hubungan antara dua variabel maka peneliti menggunakan teknik analisis korelasi yaitu korelasi product moment pearson.

\section{HASIL DAN PEMBAHASAN}

\section{Kemenarikan Interperonal Konselor}

Skala kemenarikan konselor ini diukur berdasarkan persepsi siswa terhadap konselornya. Setelah dilakukan analisis data dilakukan pengkategorian tingkat kemenarikan konselor ke dalam empat kategori yaitu; sangat menarik, menarik, cukup menarik dan kurang menarik. Pengkategorian ini berdasarkan pengisian skala kemenarikan interpersonal sesuai yang dipersepsi siswa SMA Negeri di kota Malang.

Tabel 1

Kategori Tingkat Kemenarikan Interpersonal Konselor Didasarkan Aspek Stabilitasemosional dan

\begin{tabular}{lllll}
\multicolumn{5}{c}{ Moral } \\
Interval & $\begin{array}{l}\text { Klasifikasi } \\
\text { Kemenarikan } \\
\text { Konselor }\end{array}$ & Frekuensi & Persentase & $\begin{array}{l}\text { Kategori } \\
\text { Responden }\end{array}$ \\
\hline $28-34$ & Sangat menarik & 129 & $52,4 \%$ & Sangatbanyak \\
$21-27$ & Menarik & 111 & $45,2 \%$ & Banyak \\
$14-20$ & Cukup menarik & 6 & $2,4 \%$ & Cukup banyak \\
$7-13$ & Kurang menarik & 0 & $0 \%$ & Sedikit \\
\hline
\end{tabular}

\section{Stabilitas Emosional dan Moral}

Persepsi siswa terhadap tingkat stabilitas emosional konselor, Sebagian besar siswa sudah memiliki persepsi yang baik terhadap konselor SMAN di kota malang memiliki tingkat kemenarikan interpersonal yang sangat menarik karena tingkat stabilitas emosional dan moral yang dimiliki konselor tersebut. Stabilitas emosional dan moral membuat konselor cukup menarik dan tidak ditemukan siswa yang mempersepsi konselornya sebagai pribadi yang kurang menarik. Selanjutnya, tingat kemenarikan interpersonal konselor didasarkan pada aspek stabilitas emosi dan moral dapat dilihat apada tabel 1 .

\section{Kompetensi Sosial}

Respon siswa terhadap tingkat kompetensi sosial konselor di SMAN kota malang dinilai sangat baik. Siswa menganggap konselor memiliki tingkat kemenarikan inter- personal yang sangat menarik karena tingkat kompetensi sosial yang dimiliki konselor tersebut, sehingga siswa mengangap konselor mempunyai kepribadian yang menarik dan tidak ditemukan siswa yang mempersepsi konselornya sebagai pribadi yang kurang menarik. Respon siswa terhadap kemenarikan konselor berdasarkan aspek komepetensi sosialnya dapat dilihat pada tabel 2 .

Tabel 2

Kategori Tingkat Kemenarikan Interpersonal Konselor Didasarkan Aspek Kompetensi Sosial

\begin{tabular}{|c|c|c|c|c|}
\hline Interval & $\begin{array}{l}\text { Klasifikasi } \\
\text { Kemenarikan } \\
\text { Konselor }\end{array}$ & Frekuen si & persentase & $\begin{array}{l}\text { Kategori } \\
\text { Responden }\end{array}$ \\
\hline $59-72$ & Sangat menarik & 51 & $20,7 \%$ & $\begin{array}{l}\text { Sangat } \\
\text { banyak }\end{array}$ \\
\hline $45-58$ & Menarik & 169 & $68,7 \%$ & Banyak \\
\hline $31-44$ & Cukup menarik & 26 & $10,6 \%$ & $\begin{array}{l}\text { Cukup } \\
\text { banyak }\end{array}$ \\
\hline $17-30$ & Kurang menarik & 0 & $0 \%$ & Sedikit \\
\hline
\end{tabular}

Tabel 3

Kategori Tingkat Kemenarikan Interpersonal Konselor Didasarkan Aspek Kompetensi Intelektual

\begin{tabular}{cllll}
\hline Interval & $\begin{array}{l}\text { Klasifikasi } \\
\text { Kemenarikan } \\
\text { Konselor }\end{array}$ & Frekuensi & Persentase & $\begin{array}{l}\text { Kategori } \\
\text { Responden }\end{array}$ \\
\hline $30-36$ & Sangat menarik & 88 & $35,8 \%$ & Sangat banyak \\
$23-29$ & Menarik & 115 & $46,7 \%$ & Banyak \\
$16-22$ & Cukup menarik & 43 & $17,5 \%$ & Cukup banyak \\
$9-15$ & Kurang menarik & 0 & $0 \%$ & Sedikit \\
\hline
\end{tabular}

\section{Kompetensi Intelektual}

Respon siswa terhadap tingkat kompetensi intelektual konselor di SMAN kota malang juga menggambarkan hasil yang baik. Siswa mempunyai persepsi konselor memiliki tingkat kemenarikan interpersonal yang menarik karena tingkat kompetensi intelektual yang dimiliki konselor, sehingga siswa merasa konselor mempunyai kepribadian yang menarik. Respon siswa terhadap kemenarikan konselor berdasarkan aspek kompetensi intelektual dapat dilihat pada tabel 3.

\section{Rasa Estetika}

Rasa estetika konselor juga menjadi salah satu penilaian 
dalam menentukan tingkat kemenarikan koselor. Respon siswa terhadap rasa etetika yang dimiliki konselor sangat baik. Siswa mempunyai persepsi bahwa konselor di SMAN kota malang memiliki tingkat kemenarikan interpersonal yang sangat menarik karena tingkat rasa estetika yang dimiliki konselor. Siswa menganggap konselor menarik dan tidak ditemukan siswa yang mempersepsi konselornya sebagai pribadi yang kurang menarik. Respon siswa terhadap kemenarikan konselor berdasarkan rasa estetika dalam bentuk tabel, dapat dilihat dalam tabel 4 .

Tabel 4

Kategori Tingkat Kemenarikan Interpersonal Konselor Didasarkan Aspek Rasa Estetika

\begin{tabular}{cllll}
\hline \multirow{2}{*}{ Interval } & $\begin{array}{l}\text { Klasifikasi } \\
\text { Kemenarikan } \\
\text { Konselor }\end{array}$ & Frekuensi & Persentase & $\begin{array}{l}\text { Kategori } \\
\text { Responden }\end{array}$ \\
\hline $50-61$ & Sangat menarik & 100 & $40,7 \%$ & Sangat banyak \\
$38-49$ & Menarik & 121 & $49,1 \%$ & Banyak \\
$26-37$ & Cukup menarik & 25 & $10,2 \%$ & Cukup banyak \\
$14-25$ & Kurang menarik & 0 & $0 \%$ & Sedikit \\
\hline
\end{tabular}

\section{Motivsai Siswa dalam Mengikuti Bimbingan}

\section{Kelompok}

Sedangkan skala motivasi siwa ini diukur berdasarkan apa yang dialamai siswa itu sendiri. Setelah dilakukan analisis data dilakukan pengkategorian tingkat kemenarikan konselor ke dalam empat kategori yaitu; sangat termotivasi, termotivasi, cukup termotivasi dan kurang termotivasi. Hasil pengkategorian ini berdasarkan pengisian skala motivasi siwa dalam mengikuti bimbingan kelompok SMA Negeri di kota Malang.

\section{Motivasi Intrinsik}

Motivasi Intrinsik ialah motivasi yang berasal dari dalam diri siswa sendiri. Motivasi intrinsik menjadi salah satu aspek yang menentukan tingkat kemenarikan konselor. Respon siswa SMAN di kota Malang dalam mengikuti bimbingan kelompok ditinjau dari motivasi Instrinsiknya terdapat siswa yang cukup termotivasi dan terdapat pula yang sangat termotivasi, serta tidak ditemukan siswa yang kurang termotivasi dalam mengikuti bimbingan kelompok yang diselenggarakan oleh konselornya. Selanjutnya motivasi siswa dalam mengikuti bimbingan kelompok dilihat dari motivasi intrinsiknya dapat dilihat dalam tabel 5.
Tabel 5

Kategori Motivasi Siswa dalamMengikuti Bimbingan Kelompok Ditinjau dariMotivasi Intrinsiknya

\begin{tabular}{|c|c|c|c|c|}
\hline Interval & $\begin{array}{l}\text { Klasifikasi } \\
\text { Motivasi } \\
\text { Siswa }\end{array}$ & Frekuensi & Prosentase & $\begin{array}{l}\text { Kategori } \\
\text { Responden }\end{array}$ \\
\hline $93-114$ & $\begin{array}{l}\text { Sangat } \\
\text { Termotivasi }\end{array}$ & 101 & $41,1 \%$ & $\begin{array}{l}\text { Sangat } \\
\text { banyak }\end{array}$ \\
\hline $71-92$ & Termotivasi & 142 & $57,7 \%$ & Banyak \\
\hline $49-70$ & $\begin{array}{l}\text { Cukup } \\
\text { Termotivasi }\end{array}$ & 3 & $1,2 \%$ & Cukup banyak \\
\hline $27-48$ & $\begin{array}{l}\text { Kurang } \\
\text { Termotivasi }\end{array}$ & 0 & $0 \%$ & Sedikit \\
\hline
\end{tabular}

\section{Motivasi Ekstrinsik}

Motivasi Ekstrinsik ialah motivasi yang berasal dari luar diri siswa sendiri. Motivasi Ekstrinsik menjadi salah satu aspek yang menentukan tingkat motivasi siswa dalam mengikuti kegiatan bimbingan kelompok. Respon siswa SMAN di kota malang sangat termotivasi dalam mengikuti bimbingan kelompoksedangkan sebagian siswa lain merasa cukup termotivasi dan tidak ditemukan siswa yang kurang termotivasi dalam mengikuti bimbingan kelompok yang diselenggarakan oleh konselornya. Selanjutnya Motivasi siswa dalam mengikuti bimbingan kelompok ditinjau dari motivasi ekstrinsiknya dapat dilihat dalam tabel 6 sebagai berikut.

Tabel 6

Kategori Motivasi Siswa dalam Mengikuti Bimbingan Kelompok Ditinjau dari Motivasi Intrinsiknya

\begin{tabular}{lllll}
\hline Interval & $\begin{array}{l}\text { Klasifikasi } \\
\text { Motivasi Siswa }\end{array}$ & Frekuensi & Prosentase & $\begin{array}{l}\text { Kategori } \\
\text { Responden }\end{array}$ \\
\hline $73-89$ & Sangat & 25 & $10,2 \%$ & $\begin{array}{l}\text { Sangat } \\
\text { banyak }\end{array}$ \\
& Termotivasi & & & $\begin{array}{l}\text { Banyak } \\
\text { Cukup banyak }\end{array}$ \\
$36-72$ & Termotivasi & 174 & $70,7 \%$ & Sedikit \\
& Cukup & 47 & $19,1 \%$ & \\
\hline \multirow{2}{*}{$22-38$} & Termotivasi & & $0 \%$ & \\
& Kurang & 0 & $0 \%$ & \\
\hline
\end{tabular}

Proses uji normalitas data ditelusuri dengan menggunakan uji kolmogorov simirnov. Uji ini dilakukan untuk mengetahui apakah sebaran data penelitian telah terdistribusi normal ataukah tidak. variabel X (kemenarikan interpersonal konselor) memiliki nilai signifikansi $(0,124)$ $>(0,05)$ maka data variabel $X$ adalah berdistribusi normal. Sedangkan pada variabel Y (motivasi siswa mengikuti bimbingan kelompok) memiliki nilai signifikansi adalah $(0,130)>(0,05)$ data variabel $Y$ dapat dikatakan berdistribusi normal. Berdasarkan uji normalitas sebaran 
data dari variabel kemenarikan interpersonal konselor dan motivasi siswa mengikuti bimbingan kelompok dapat dilihat pada tabel 7.

Tabel 7

\begin{tabular}{lllll}
\multicolumn{5}{c}{ Hasil Uji Linieritas } \\
\hline Model & df & Mean Square & F & Sig. \\
\hline Regression & 1 & 23153.457 & 154.297 & $.000^{\circ}$ \\
\hline Residual & 244 & 150.058 & & \\
\hline Total & 245 & & & \\
\hline
\end{tabular}

Dari hasil analisis dengan tabel model anova menunjukkan bahwa sig. $(0,000)<$ á $(0,05)$, dan $F$ hitung $(154,297)>$ dari $\left(F\right.$ tabel $\left.{ }_{(1 ; 244 ; 0,05)}<3,89\right)$, dari situ dapat disimpulkan bahwa sebaran dari masingmasing variabel adalah linier. Hal ini diperkuat juga dengan hasil gambar diagram pada lampiran 5, yang mendekati diagonal lurus yang bertanda juga bahwa linier. Selanjutnya berdasarkan perhitungan yang telah dilakukan dengan menggunakan teknik analisa korelasi produvt moment pearson dan diperoleh koofisien korelasi sebesar $r=0,622$ dan sig $(0,000)<p(0,05)$. Dimana $\mathrm{p}$ (probability eror) merupakan toleransi kemungkinan analisis meleset. Dengan melihat hasil analisis tersebut berarti ada hubungan yang positif dan signifikan antara kemenarikan interpersonal konselor dan motivasi siswa dalam mengikuti bimbingan kelompok.

Selanjutnya dari hasil uji korelasi ini juga dapat dicari nilai koefisien determinannya, yaitu untuk mengetahui seberapa besar pengaruh kemenarikan interpersonal konselor ini terhadap motivasi siswa dalam mengikuti bimbingan kelompok.

Tabel 8

Hasil Uji Korelasi

\begin{tabular}{ccccc}
\hline Variabel & $\mathbf{R}$ & Sig & Ket & Kesimpulan \\
\hline$X-Y$ & 0,622 & 0,000 & Sig $<0,05$ & Signifikan \\
& & & & \\
\hline
\end{tabular}

Ini berarti bahwa pengaruh kemenarikan interpersonal konselor terhadap motivasi siswa dalam mengikuti bimbingan kelompok adalah sebesar 38,7 \%, sedangkan 61,3\% dipengaruhi oleh faktor lain.

Dari penelitian sebelumnya yang dilakukan oleh Gumilang G.S (2016) di SMKN kota Malang dapat ditarik kesimpulan bahwa konselor dalam berkomunikasi dengan siswa masih mengalami hambatan yaitu diantaranya dalam menggunakan bahasa yang menggunakan bahasa campuran/eklektik antara indonesia dan jawa. Hal tersebut dapat ditarik makna bahwa konselor masih kurang dalam self-culture awareness sehingga konselor bingung dan canggung menghadapi konseli yang berlatarbelakang bahasa \& budaya berbeda. Selain itu, konselor juga kurang mengimprovisasi dalam hal artikulasi sehingga membuat konseli kurang memahami apa yang di maksudkan konselor.

Sementara hasil penelitian yang dilakukan oleh Kommaraju M, (2013) menunjukkan hasil bahwa perbedaan konsep diri individu dalam akademis siswa dan orientasi motivasional membedakan opini mereka mengenai apa yang mereka nilai pada guru 'ideal'. Sebagian besar siswa menilai, guru yang mudah untuk ditemui, membangun hubungan baik, dan memberikan umpan balik yang membangun dapat dianggap lebih mungkin untuk membantu siswa yang mendapat motivasi ekstrinsik mendapatkan nilai bagus dan mempersiapkan diri dengan sukses untuk karir masa depan.

Dayakisni dan Hudaniah (2001) mengungkapkan bahwa kesukaan pada orang lain, sikap positif dan daya tarik seseorang, disebut sebagai daya tarik interpersonal. Kemenarikan ini merupakan serangkaian kecakapan personal yang dimiliki oleh satu individu berupa keterampilan interpersonal yang dipersepsi sebagai suatu hal positif dan menarik yang terdapat dalam diri seseorang. Hubungan antara siswa dengan guru yang sehat adalah prasyarat untuk melibatkan siswa dalam kegiatan belajar. Dalam Penelitian yang dilakukan oleh Misbah, Z., Gulikers, J., Maulana, R., \& Mulder, M. (2015) telah meneliti hubungan antara siswa dengan guru menggunakan perspektif interpersonal, dengan menggunakan perspektif ini, penelitian menunjukkan bahwa cara siswa memandang guru mereka secara interpersonal (Perilaku Interpersonal Guru) berhubungan dengan prestasi akademik siswa, sikap terhadap pembelajaran dan motivasi belajar siswa. Sejalan dengan hasil penelitian yang dilakukan oleh Maulana, R., Opdenakker, M. C., \& Bosker, R. (2014) yang menunjukkan bahwa hubungan antara guru dengan siswa yang baik dapat menghasilkan lingkungan kelas yang produktif. Terutama, 
hubungan interpersonal guru dengan siswa berkualitas tinggi, meningkatkan motivasi siswa, Sebaliknya, hubungan interpersonal antara siswa dengan guru yang buruk sering tercermin dalam penurunan motivasi belajar siswa. Kondisi kemenarikan yang ada pada konselor dapat dilihat dari pandangan dan persepsi siswa terhadap figur konselornya. Pandangan positif dan antusiasnya siswa pada seorang konselor merupakan indikator yang dapat dilihat secara langsung.Persepsi siswa terhadap kemenarikan konselor di Kota Malang salah satunya dapat diketahui dari hasil penelitian ini.

Kategori sangat menarik yang teranalisis menunjukan bahwa siswa tersebut telah merasa bahwa apa yang ada dan melekat pada karakteristik konselornya tersebut adalah sesuatu yang positif dan menarik. Sedang skor dalam kategori menarik yang mendominasi ditiga aspek yaitu kompetensi sosial, kompetensi intelektual dan rasa estetika yang melekat pada konselor, mengindikasikan persepsi dan pandangan yang baik terhadap konselornya meskipun tidak beranggapan semenarik apa yang dipersepsi siswa dengan kategori sangat menarik namun hal ini juga menjadikan indikasi bahwa sebagian besar konselor telah memiliki kharakter yang positif di mata siswanya. Sedang yang masuk dalam kategori cukup, mengindikasikan bahwa siswa tersebut berpersepsi sewajarnya terhadap konselornya. Konselor dimata siswa dalam kategori ini merupakan pribadi yang biasa-biasa saja. Serta dengan tidak ditemukannya siswa yang mempersepsi konselornya secara negatif ini memberikan indikasi bahwa di kota malang sudah banyak konselor yang memiliki kharakter yang menyenangkan di mata siswanya.

Sedangkan menurut pendapat Uno (2008) motivasi adalah kekuatan, baik dari dalam maupun dari luar yang mendorong seseorang untuk mencapai tujuan tertentu yang telah ditetapkan sebelumnya. Para ilmuwan, peneliti, dan guru sepakat bahwa siswa yang termotivasi untuk belajar lebih cenderung terlibat, bertahan, dan mengeluarkan usahauntuk penyelesaian tugas daripada mereka yang tidak termotivasi. Dengan demikian, bisa dikatakan bahwa "motivasi menyediakan sumber energi yang menjadi tanggung jawab mengapa peserta didik memutuskan untuk melakukan usaha, bagaimana lama mereka bersedia untuk mempertahankan suatu aktivitas, seberapa keras mereka akan mengejarnya, dan bagaimana hubungannya dengan kegiatan itu (Di Serio, Á., Ibáñez, M. B., \& Kloos, C. D, 2013).

Motivasi siswa dalam mengikuti bimbingan kelompok ditentukan oleh banyak faktor baik dari dalam maupun dari luar yang diantaranya Keinginan dan hasrat melakukan kegiatan, Dorongan dan kebutuhan melakukan kegiatan (bimbingan kelompok), Harapan dan cita-cita pada diri siswa, Lingkungan sekolah yang kondusif, Penguatan sebagai wujud penghoramatan dan penghargaan atas diri, serta Kegiatan bimbingan yang menarik. Demikian pula, persepsi siswa terhadap perilaku interpersonal guru sangat terkait dengan motivasi dan prestasi mereka dalam semua kegiatan pembelajaran (Maulana, R., Opdenakker, M. C., den Brok, P., \& Bosker, R, 2011)

Skor sangat tinggi dari skala motivasi siswa dalam mengikuti bimbingan kelompok ini mengindikasikan bahwa siswa telah memiliki motivasi yang sangat kuat dalam mengikuti bimbingan kelompok. Siswa tersebut telah merasa bahwa apa yang disampaikan melalui bimbingan adalah sesuatu yang penting yang memiliki manfaat tersendiri bagi siswa tersebut. Sedang skor mayoritas baik dari motivasi intrinsik maupun ekstrinsik yaitu yang skor dalam kategori tinggi yang itu merupakan skor mayoritas mengindikasikan hal ini menjadikan indikasi bahwa sebagian besar siswa telah memiliki kesadaran akan pentingnya bimbingan, dan juga dapat diketahui bahwa bimbingan merupakan suatu yang menyenangkan baik dari segi materi, media, isi maupun pematerinya yang dalam hal ini adalh konselor. Sedang yang masuk dalam kategori cukup, mengindikasikan bahwa siswa tersebut cukup termotivasi degan adanya bimbingan kelompok. Serta dengan tidak ditemukannya siswa yang memiliki motivasi rendah di SMA Negeri menjadi indikasi bahwa siswa-siswa yang ada pada sekolah ini telah memiliki dorongan tersendiri untuk antusias dalam mengikuti bimbingan kelompok yang diselenggarakan oleh konselor.

Dari hasil penelitian ini maka dapat dikatakan bahwa secara umum siswa SMA Negeri telah memiliki motivasi yang tinggi dalam mengikuti bimbingan kelompok. Hal ini mengindikasikan bahwa suatu hal yang penting yaitu bimbingan kelompok sudah menjadi suatu kebutuhan tersendiri bagi siswa guna mendukung aktivitas dan 
perkembanganya dalam kehidupan sehari-hari.

Dari hasil pengujian hipotesis mengenai ada tidaknya hubungan yang signifikan antara kemenarikan interpersonal konselor dan motivasi siswa SMA Negeri dalam mengikuti bimbingan kelompok di Kota Malang, maka melalui uji chi-kuadrat diperoleh (Asymp. Sig sebesar $0,000<0,05)$ maka dapat diketahui bahwa ada hubungan yang signifikan antara kemenarikan interpersonal konselor dan motivasi siswa dalam mengikuti bimbingan kelompok. Hal ini juga diperkuat dengan perhitungan teknik analisis product moment diperoleh hasil bahwa nilai r hitung lebih besar dari nilai $r$ tabe/ harga kritik yaitu nilai $r x y=$ $0,622>$ dan nilai $r$ tabel $=0,138$ dengan taraf kepercayaan $95 \%=0,000$ ini menyimpulkan bahwa: Hipotesis (Hi) diterima yaitu "Ada hubungan yang signifikan antara kemenarikan interpersonal konselor dan motivasi siswa SMA Negeri dalam mengikuti bimbingan kelompok di KotaMalang". Demikian pula sebaliknya hipotesis nihil (Ho) ditolak yaitu: "Tidak ada hubungan yang signifikan antara kemenarikan interpersonal konselor dan motivasi siswa SMA Negeri dalam mengikuti bimbingan kelompok di Kota Malang". Pembahasan hasil penelitian di atas secara obyektif dapat dikembangkan dalam konteks penalaran lebih lanjut bahwa kemenarikan interpersonal konselor merupakan hal yang integral dengan munculnya motivasi siswa dalam mengikuti bimbingan kelompok yang diselenggarakan oleh konselor itu sendiri. Dalam hal ini kemenarikan konselor mempunyai peran penting dalam membangkitkan motivasi siswa dan lebih lanjut memberikan peranan yang sangat penting dalam penyelenggaraan bimbingan kelompok di sekolah sebagai salah satu layanan dalam pelaksaaan bimbingan dan konseling disekolah, dimana hal ini juga dapat diketahui dengan besarnya pengaruh kemenarikan interpersonal sebesar 38,7 \% terhadap motivasi. Ini merupakan sesuatu yang jelas dapat dikenali bahwa kemenarikan interpersonal konselor ikut mempengaruhi motivasi siswa, meskipun masih banyak lagi yaitu sebesar $61,3 \%$ elemen lain yang ikut mempengaruhinya.

Konselor yang memiliki kemenarikan interpersonal yang tinggi akan banyak membangkitkan iklim persahabatan dan suasana yang menyenangkan bagi siswanya. Dengan situasi yang tercipta semacam itu maka konselor akan semakin dekat dengan siswanya sehingga hal tersebut akan mempermudah dalam memberikan layanan kepada siswa dengan hasil yang optimal. Kemenarikan interpersonal ini akan membuat siswa bersemangat dan termotivasi lebih tinggi lagi dalam mengikuti bimbingan yang diberikan konselor. Dengan kemenarikan interpersonal konselor itu pula maka bimbingan kelompok yang merupakan salah satu layanan yang diberikan akan mendukung tercapainya tujuan pendidikan disekolah secara umum.

Menurut Duffy FD,et.al (Benson, 2014) Keterampilan interpersonal, bagaimanapun, secara inheren berbasis hubungan dan berorientasi pada proses, Mereka didefinisikan oleh efek komunikasi terhadap orang lain. Sementara Gardner mengatakan keterampilan komunikasi interpersonal mengacu pada kemampuan seseorang untuk berkomunikasi secara kooperatif dalam kelompok, Baik verbal maupun non verbal dan seseorang yang memiliki kemampuan komunikasi interpersonal yang efektif dan Peka terhadap perasaan dan emosi orang lain di sekitarnya (Suhaimi, A. W., Marzuki, N. A., \& Mustaffa, C. S, 2014). Sedangkan Lolli (2013) dalam Journalnya Interpersonal communication skills and the young hospitality leader: Are they prepared?mendefinisikan keterampilan komunikasi interpersonal sebagai komunikasi yang terjadi antara dua atau lebih individu pada tingkat pribadi tatap muka. Dari beberapa Pengertian diatas dapat di ambil Kesimpulan Keterampilan Komunikasi Interpersonal adalah komunikasi yang dilakukan dua orang atau lebih baik verbal atau non verbal yang dapat membuat suasana kelompok menjadi kooperatif, efektif dan peka terhadap perasaan orang lain yang disekitarnya.

Johnson \& Johnson (1991) menyatakan bahwa seseorang berkomunikasi dengan orang lain harus mampu memulai, mengembangkan, dan memelihara komunikasi yang akrab, hangat dan produktif dengan orang lain, maka diperlukan sejumlah keterampilan berkomunikasi.Pesan komunikasi dapat memiliki banyak bentuk. Menyampaikan, dan menerima pesan ini merupakan salah satu atau kombinasi tertentu dari panca indera, walaupun biasanya menganggap pesan selalu dalam bentuk verbal (lisan atau tertulis), selain verbal dapat juga berkomunikasi secara non verbal (gerakan). Keberadaan komunikasi interpersonal telah berperan aktif dalam kehidupan.Adapun fungsi komunikasi interpersonal, yaitu (a) Memenuhi kebutuhan sosial dan 
psikologis.Dengan komunikasi interpersonal, kita bisa memenuhi kebutuhan sosial dan psikologis kita.Pada dasarnya manusia merupakan makhlk sosial, yaitu orang yang membutuhkan orang lain, sebagaimana halnya manusia membutuhkan makanan, minuman, perlindungan, dan sebagainya, (b) Mengembangkan kesadaran diri. Melalui komunikasi interpersonal akan terbiasa mengembangkan kesadaran diri, (c) Matang akan konvensi sosial. Mengabaikan orang lain dan tidak berbicara, berarti menentang konvensi sosial dan menimbulkan kesan melalaikan orang lain, (d) Konsistensi hubundan dengan orang lain, (e) Mendapatkan informasi yang banyak, (f) Bisa memengaruhi orang lain atau dipengaruhi oleh orang lain.

Motivasi sebagian siswa untuk terlibat dalam tugas sekolah, tergantung, sejauh mana mereka menghargai, atau percaya bahwa aktivitas pembelajaran itu bermanfaat dan penting. Siswa yang menghargai apa yang mereka ajarkan cenderung berprestasi tinggi, keterlibatan lebih dalam aktivitas kelas, dan tingkat minat yang lebih tinggi. Sementara siswa yang tidak terlibat cenderung kehilangan minat pada materi pelajaran, mudah terganggu, dan menunjukkan sedikit usaha (Shin, T. S., Ranellucci, J., \& Roseth, C. J, 2017)

Motivasi sangat diperlukan dalam melakukan setiap aktivitas (Komarraju, 2013). Motivasi juga berpengaruh penting pada sikap peserta didik dan perilaku belajar dan motivasi akademik merupakan penentu utama kinerja akademik dan patut mendapat perhatian lebih (Panisoara, G., Duta, N., \& Panisoara, I. O, 2015). Apabila tidak ada motivasi, maka kegiatan yang dilakukan tidak akan mencapai hasil yang maksimal bahkan akan jauh dari tujuan yang ingin dicapai. Tanpa motivasi, individu tidak akan bergairah, akan melakukan kegiatan sekedarnya saja atau tidak bisa melakukan apapun karena tidak mempunyai motivasi.

Dari perspektif pendidikan, istilah motivasi oleh Nazir (2003) menyatakan bahwa motivasi sebagai stimulus untuk keinginan belajar sesuatu (Abdullah, A., \& Yih, T. $Y$, 2014). Nilson (2010) mengemukakan bahwa seorang pendidik hendaknya ingin menciptakan ketertarikan yang tulus terhadap kegiatan pembelajaran, rasa relevansinya dan penerapannya terhadap kehidupan dan dunia, rasa pencapaian (untuk kepentingannya sendiri) dalam menguasainya, dan rasa untuk memunculkan motivasi kepada siswa. Motivasi siswa merupakan hal pokok yang penting untuk dibangkitkan, sebagai penopang akan terciptanya keefektifan dalam penyelenggaraan bimbingan kelompok. Salah satu cara yang dapat ditempuh adalah dengan meningkatkan kemenarikan interpersonal konselor.

Kemenarikan Interpersonal konselor yang baik akan membuat siswa senang dalam menerima layanan dan lebih efektif dalam menyampaikan pesan. Siswa akan lebih memperhatikan dan tidak mudah bosan saat mengikuti kegiatan layanan dan tentu konselor juga akan disenangi oleh siswa. Konselor yang tidak mempedulikan akan pentingnya kemenarikan interpersonal dalam interaksinya khususnya dalam berinteraksi dengan siswa, maka ia kurang disukai oleh siswanya, dianggap kurang penting peranannya, dan lebih parah akan diabaikan begitu saja. Akibat lebih lajut dari diabaikanya konselor karena tidak memiliki kemenariakan interpersonaladalah bimbingan yang diberikan tidak akan efektif, tidak mencapai sasaran yang diinginkan, dan tujuan pendidikan yang sebenarnya tidak akan tercapai.

Dengan adanya kemenarikan interpesonal yang baik dapat mengarahkan siswa untuk terlibat aktif dalam melaksanakan kegiatan bimbingan kelompok. Siswa yang terlibat aktif dalam bimbingan kelompok menunjukkan bahwa dirinya senang mengikuti kegitakan tersebut.Dalam bimbingan kelompok, suasana kelompok, yaitu hubungan dari semua anggota yang terlibat dalam kelompok, dapat dimanfaatkan untuk saling menggali informasi, tanggapan, pendapat atau reaksi apapun selama konseling terjadi. $\mathrm{Hal}$ ini akan sangat menguntungkan bagi para siswa. Jika situasi dalambimbingan kelompok menyenangkan, maka bukan tidak mungkin para siswa menemukan hal-hal yang baru yang pada akhirnya akan bisa mengatasi permasalahan motivasi belajar yang sedang dihadapinya (Prayitno dan Amti, 2004).

\section{KESIMPULAN}

Terdapat hubungan yang positif dan signifikan antara kemenarikan interpersonal konselor dan motivasi siswa SMA Negeri dalam mengikuti bimbingan kelompok di Kota Malang. Hal ini memberikan menandakan bahwa kemenarikan interpersonal konselor memiliki peranan penting bagi terciptanya motivasi siswa dalam mengikuti 
bimbingan kelompok yang dielenggarakan oleh konselor di SMA Negeri di kota Malang. Besar peranan kemanarikan interpersonal konselor yaitu memberi sumbangan sebesar 38,7 \% bagi terciptanya motivasi siswa dalam mengikuti bimbingan kelompok dan sedangkan sisanya yauitu sebesar 61,3\% ditentukan oleh elemen lain. Bagi Konselor, Kemenarikan interpersonal dan motivasi siswa adalah dua elemen penting dalam keefektifan penyelenggaraan bimbingan kelompok, untuk itu sebagai pemegang peran kunci dalam penyelenggaraan bimbingan kelompok disekolah, maka kedua hal tersebut hendaklah tercapai, disamping memang banyak faktor lain yang juga ikut mendukung. Konselor hendaknya senantiasa menambah wawasan dan ketrampilan akan kemenarikan interpersonal ini khususnya yang berkaitan erat dengan motivasi siswa guna dapat memberikan bimbingan kelompok secara optimal.

\section{REFERENSI}

Abdullah, A., \& Yih, T. Y. (2014). Implementing Learning Contracts in a Computer Science Course as a Tool to Develop and Sustain Student Motivation to Learn. Procedia-Social and Behavioral Sciences, $123,256-26$

Benson, B. J. (2014). Domain of Competence: Interpersonal and Communication Skills. Academic Pediatrics, 14(2), S55-S65

Dayakisni dan Hudainah.(2001). Psikologi Sosial.Malang: Universitas Muhamadiyah

Di Serio, Á., Ibáñez, M. B., \& Kloos, C. D. (2013). Impact of an Augmented Reality System on Students' Motivation for a Visual Art Course. Computers $\mathcal{E}$ Edu-cation, 68, 586-596.

Gumilang, G.S. (2015) Evaluasi Keterampilan Komunikasi Interpersonal antara Konselor dengan Siswa, Staf Sekolah, dan Orangtua di SMKN Kota Malang. PSIKOPEDAGOGIA Jurnal Bimbingan dan Konseling,4,(1).

Gumilang, G. S. (2017). Evaluasi Keterampilan Komunikasi Interpersonal Antara Konselor Dengan Siswa, Staf Sekolah, Dan Orangtua SMKN Di Kota Malang. Jurnal Konseling Indonesia, 1 (1).

Hanurawan, F. (2007).Pengantar Psikologi Sosial.Malang: Rosindo.

Irawan, Edy. (2013). Efektivitas Teknik Bimbingan
Kelompok Untuk Meningkatkan Konsep Diri Remaja (Studi Pre-Eksperimen pada Siswa Kelas X SMK Yapema Gadingrejo Lampung. PSIKOPEDAGOGIA Jurnal Bimbingan dan Konseling,2,(1)

Johnson, D. W. \& Johnson, F. P. (1991).Fourth Edition Joining Together Group Theory and Groups skills. New Jersey: Prentice-Hall Inc

Komarraju, M. (2013). Ideal Teacher Behaviors: Student Motivation and Self-efficacy Predict Preferences. Teaching of Psychology, 40(2), 104-110.

Lolli, J. C. (2013). Interpersonal Communication Skills and the Young Hospitality Leader: Are they Prepared?. International Journal of Hospitality Management, 32, 295-29.

Maulana, R., Opdenakker, M. C., \& Bosker, R. (2014). Teacher-student Interpersonal Relationships do Change and Affect Academic Motivation: A Multilevel Growth Curve Modelling. British Journal of Educational Psychology, 84(3), 459-482.

Maulana, R., Opdenakker, M. C., den Brok, P., \& Bosker, R. (2011). Teacher Student Interpersonal Relationships in Indonesia: Profiles and Importance to Student Motivation. Asia Pacific Journal of Education, 31(01), 33-49.

Misbah, Z., Gulikers, J., Maulana, R., \& Mulder, M. (2015). Teacher Interpersonal Behaviour \& Student Motivation Competen Vocational Education Evidenc from Indonesia.Teaching and Teacher Education, 50, 79. 89. 